
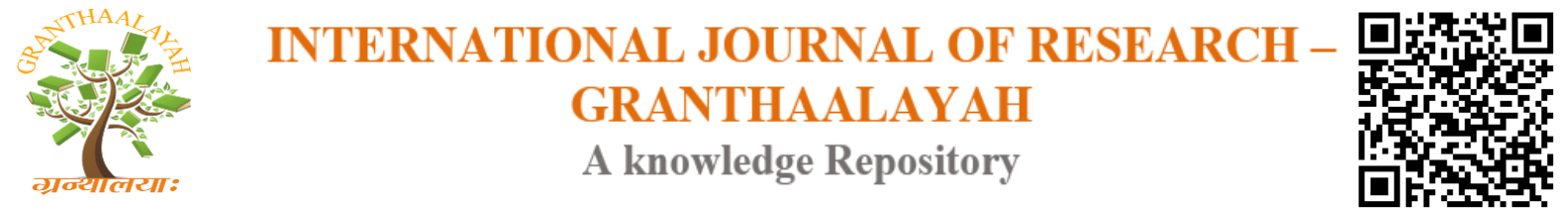

Management

\title{
A STUDY ON THE AWARENESS, PREFERENCE AND SATISFACTION OF POLICY HOLDERS TOWARDS LIC WITH SPECIAL REFERENCE TO MALAPPURAM DISTRICT
}

\author{
Jayapriya C. K. ${ }^{* 1}$, Dr. P. S. Chandni ${ }^{2}$ \\ ${ }^{* 1}$ M.Phil Scholar, P.G. \& Research Dept of Commerce, Sree Narayana Guru College, \\ Coimbatore, INDIA \\ ${ }^{2}$ Head of Department, P.G. \& Research Dept of Commerce, Sree Narayana Guru College, \\ Coimbatore, INDIA
}

DOI: https://doi.org/10.29121/granthaalayah.v4.i10.2016.2495

\section{ABSTRACT}

Life insurance is actually an agreement between the insured and the insurer in which the policy holder accepts to pay regular premium to the insurer. In return, the insurer guarantees monetary protection to the insured in case of any accident or mishaps. If the insured dies in accident, financial help is provided to his family members. Thus, life insurance is necessary as it provides protection to not only for the insured but also to the family of insured in case of any unwanted disaster. A thriving insurance sector is very important to every modern economy. Firstly because it encourages the habit of saving, secondly because it provides safety to rural and urban enterprises and productive individuals.

At present the number of customers investing in LIC is increasing rapidly due to various reasons. Some of them are investing to get tax advantage, while some others are for children education, children marriage, pension for future etc. The number of LIC agents are also increasing.They are providing adequate services to their customers. This study helps to find out the awareness level of customers towards various schemes of LIC and to measure the preference and satisfaction of policy holders towards LIC. The data required for the study are collected from 100 customers of LIC from Malappuram district through well designed questionnaire. Simple percentage and chi square test are used for analyzing the collected data.

Keywords:

Life insurance, Awareness, Preference.

Cite This Article: Jayapriya C. K., and Dr. P. S. Chandni, "A STUDY ON THE AWARENESS, PREFERENCE AND SATISFACTION OF POLICY HOLDERS TOWARDS LIC WITH SPECIAL REFERENCE TO MALAPPURAM DISTRICT" International Journal of Research Granthaalayah, Vol. 4, No. 10 (2016): 82-90. 


\section{INTRODUCTION}

Insurance industry forms a dominant part of financial market consisting of contractual intermediaries which channelize the savings of the society to the productive sectors of the economy. The role of the insurance industry in resource mobilization is a very challenging task especially in India, on account of economic, social and educational backwardness of people for whom insurance is not an essential instrument to cover risk associated with human life. In a marketing perspective, an insurance product is categorized as an unsought product about which customers have inadequate or low awareness. Consequently, it is said that insurance product are sold rather than bought which makes the task of insurance companies really challenging since independence. Life insurance Corporation of India has been marketing insurance product as a monopoly insurer, being the unchallenged leader in the Indian insurer industry.

Life insurance business in India was being transacted by private companies until 1956. As a result of the long felt need and in the interest of insuring public, the life insurance business was nationalized in 1956. The nationalization resulted in the establishment of Life Insurance Corporation of India (LIC) by an act of the Parliament. The Corporation was formed and began to function on September1, 1956 by taking over 170 companies and 75 provident societies. The entire initial capital of Rs.5crore was contributed by the government of India.

Life insurance industry has assumed a pivotal role in the face of the rapid changes such as liberalization, globalization and privatization and also the related technological and market changes. The efforts of the industry are to be distinctly identified and every sphere of activity must be integrated vertically and horizontally to deliver significantly the service of an industry so as to get good business results. Life insurance is a long-term business with a focus on long-term financial solutions to customers. Life insurance or life assurance is basically an agreement between a life insurance company and policyholder wherein the insurance company promises to pay a defined amount to the beneficiary or nominee in return of premium in case of insured's death. Other cases or events such as critical illness, terminal illness will also be liable for the coverage, depending upon the contract. Under the same, a policyholder pays a definite amount to the insurer which is known as premium, regularly or in a lump sum.

\section{OBJECTIVE OF THE STUDY}

1) To find out the reasons for investing in the LIC of India

2) To analyze which type of insurance policies preferred by various categories of customers.

3) To analyze various services provided by LIC and to measure the level of satisfaction on services.

4) To analyze the problems faced by customers and the complaint redressal system of LIC.

\section{RESEARCH METHODOLOGY}

\section{SAMPLE SIZE}

The sample size was fixed to a number of 100 policy holders in Malappuram District 


\section{SAMPLING METHOD}

Convenient sampling method is used for the study

\section{SOURCES OF DATA}

For this study, both primary and secondary data are used .Primary data are collected directly from 100 Policy holders of LIC .Secondary data are collected from Journals, Magazines, Books and from relevant websites.

\section{TOOLS FOR DATA COLLECTION AND ANALYSIS}

A well-structured questionnaire was designed to collect data from policy holders. Simple percentage analysis, weighted rank average method and Chi-Square tests are applied for analyzing the data.

\section{LIFE INSURANCE CORPORATION OF INDIA}

The Life Insurance Corporation of India (LIC) was set-up by the Government of India to achieve the following objectives:

- Spread Life Insurance widely and in particular to the rural areas and to the socially and economically backward classes with a view to reaching all insurable persons in the country and providing them adequate financial cover against death at a reasonable cost.

- Maximize mobilization of people's savings by making insurance linked savings adequately attractive.

- Deploy the funds to the best advantage of the investors as well as the community as a whole, keeping in view national priorities and obligations of attractive return.

- Conduct business with utmost economy and with the full realization that the moneys belong to the policy holders.

- Act as trustees of the insured public in their individual and collective capacities.

- Meet the various life insurance needs of the community that would arise in the changing social and economic environment.

- Involve all people working in the corporation to the best of their capabilities in furthering the interests of the insured public by providing efficient service with courtesy.

- Promote amongst all agents and employees of the Corporation a sense of participation, pride and job satisfaction through discharge of their duties with dedication towards achievement of corporate objectives.

\section{IMPORTANT OPERATIONAL TERMS OF LIC}

\section{Life insurance;}

Life insurance is a contract that pledges payment of an amount to the person assured (or his nominee) on the happening of the event insured against. The contract is valid for payment of the insured amount during

i. The date of maturity, or 
ii. Specified dates at periodic intervals, or

iii. Unfortunate death, if it occurs earlier.

Life insurance is a contact by which you can protect yourself against specific uncertainties by paying a premium over a period.

\section{Savings and Investments;}

Insurance is a means to Save and Invest. Periodic premiums are like Savings and you are assured of a lump sum amount on maturity. A policy can come in handy at the time of your child's education or marriage. Besides, it can be used as supplemental retirement income.

\section{Tax Benefits;}

Life insurance is one of the best tax saving options today. Tax can be saved twice on a life insurance policy-once when we pay premiums and at the time of receiving maturity benefits.

\section{Premium;}

Premium is the consideration that the policyholder has to pay in order to secure the benefits offered by the insurance policy. It can be looked upon as the price of the insurance policy. It may be a one-time payment or periodical payment (Monthly Quarterly, Half yearly, Yearly). A default in premium can endanger the continuance of the policy. If that happens, the policy will be treated as lapsed and the expected benefits.

\section{Claims;}

A claim is the demand that the insurer should redeem the promise made in the contract. The insurer has then to perform his part of the contract i.e. settle the claims, after satisfying himself that all the conditions and requirements for settlement of claim have been complied with.

\section{Agent;}

An insurance company appoints representative licensed by the state, who solicits, negotiates or effects contracts of insurance, and provides service to the policyholder for the insurer.

\section{Assurance}

Is the coverage of risk on the happening of an event, which will happen during the period of insurance.

\section{Insurer;}

Is the company, which covers the risk under a policy of insurance.

\section{Insured;}

Is the person on whose life the risk is covered.

\section{Proposer;}

Is the person who seeks the insurance on the life proposed for insurance

\section{Plan of insurance;}

Is the scheme offering specified benefits. Different plans are offered by the insurer to suit the varying need of the insuring public. 


\section{Term;}

Is the period (no. of years) for which the risk on the risk on the life assured will be covered.

\section{Sum assured;}

Is the amount payable on the happening of the even specified in the policy during the term of the policy.

\section{Survival benefit;}

Is the amount (a fixed percentage of sum assured) payable under certain plans on the life assured surviving the period specified in the policy.

\section{Policy;}

Is the document issued by the insurer specifying the sum assured, plan, and term, the benefits payable under the policy and the conditions and privileges of the policy. It is an evidence of the contract of life insurance.

\section{Maturity claim;}

Is the payment of amount by the insurer on the life assured surviving the term specified in the policy.

\section{First Premium Receipt;}

Is the document issued by the insurer, as a prelude to the issue of the policy to indicate that he has accepted the risk on the life proposed for insurance.

\section{Date of commencement (DOC);}

Is the date month and year from which the risk commences under a policy.

\section{Days Of Grace;}

Is Policy holders are expected to pay premium on due dates. A period is 15-30 days is allowed as grace to make payment of premium; such period is days of grace.

\section{Due date;}

Is the date on which the installment premium to be paid under the policy falls due.

\section{Nomination;}

Is the facility available under a life insurance policy to enable the insurer to pay the benefits available under the policy to the nominated person on the death of the life assured.

\section{Assignment;}

Is the transfer of rights under the policy. 


\section{ORGANISATIONAL STRUCTURE OF LIC}

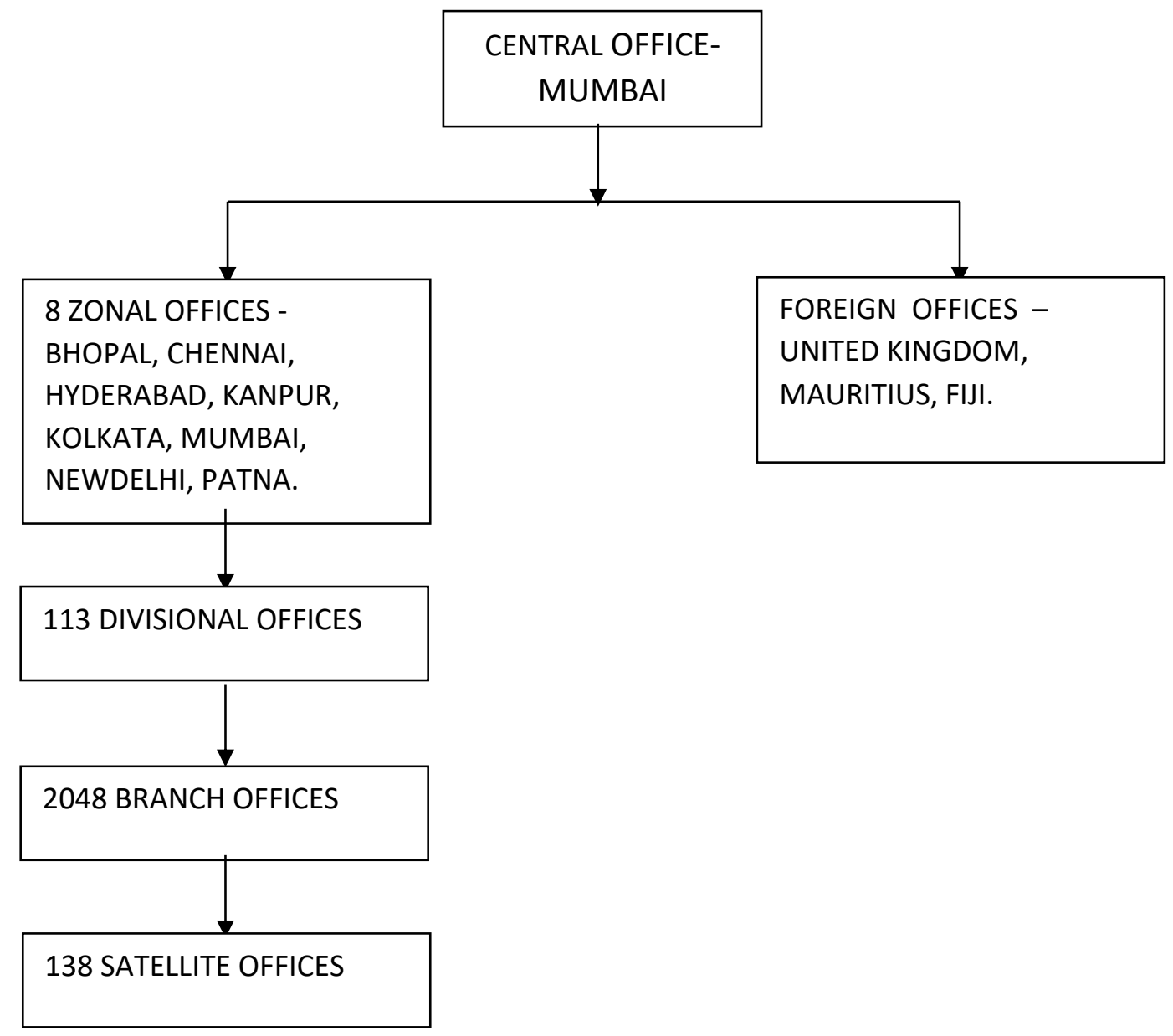

\section{BRIEF HISTORY OF IRDA}

Insurance Regulatory and Development Authority (IRDA) is a statutory body set up for protecting the interests of the policyholders and regulating, promoting and ensuring orderly growth of the insurance industry in India.

The IRDA Act, 1999 was passed as per the major recommendation of the Malhotra Committee report (1994) which recommended the establishment of an independent regulatory authority for insurance sector in India. Later, it was incorporated as a statutory body in April, 2000. The IRDA Act, 1999 also allows private players to enter the insurance sector in India besides a maximum foreign equity of 26 per cent in a private insurance company having operations in India. Considering some of the emerging requirements of the Indian insurance industry, IRDA was amended in 2002. As stated in the act mission of IRDA is "to protect the interests of the policyholders, to regulate, promote and ensure orderly growth of the insurance industry and for matters connected therewith or incidental thereto." Indian insurance industry is regulated by the terms and conditions of the IRDA. Indian law has certain expectations from the IRDA to perform in the Indian insurance industry. IRDA should protect the interest of policyholders by ensuring fair treatment by the insurance companies. The growth of insurance companies in a speedy and 
orderly manner should be taken care by the IRDA. It should monitor and implement quality competence and fair dealing of the insurance companies in the industry. IRDA should make sure that the insurers are providing precise and correct information about the products offered by them for the insurance customers. IRDA should also ensure speedy settlement of genuine claims of the policyholders and prevent malpractices in the process of claims settlement. IRDA controls all the Insurance business in India. They are setting structure and boundaries for the insurance companies to act upon. Starting from licensing to approving the products, IRDA directs the companies in India. They also protect customer interests in the country. As per current guidelines issued by IRDA, Insurance Companies are not permitted to invest in Indian Depository Receipts (IDR), while they are permitted to invest in Equity shares/ Bonds/ Debentures. IRDA needs to remove this disparity to open up investment opportunity by Insurance Companies and thereby also enhance the liquidity of IDRs (Contributed by Sanjay Banka, FCA FCS) Hence, the present work made an attempt to study the Role of IRDA in Indian Insurance sector.

\section{IMPORTANT TYPES OF LIFE INSURANCE POLICIES}

\section{i. Term Insurance Policy}

This policy is pure risk cover policy. The insured amount will be paid only if the policy holder dies in the period of policy time. The intention of this policy is to protect the policy holder's family in case of death. For example, a person who takes term policy of Rs.500000 for 20 years, if he dies before 20 years then his family will get the insured amount. If he survive after 20 years then he will not get any amount from the insurance company. It is the reason why term policies are very low cost. So, this type of policy is not suitable for savings or investment.

\section{ii. Whole Life Policy}

As the name itself says, the policy holder has to pay the premium for whole life till his death. This policy doesn't address any other needs of the policy holder. Because of these reasons, this kind of policy is not very popular or insurance company not suggesting to take this policy.

\section{iii. Endowment Policy}

It is the most popular Life Insurance Plans among other types of policies. This policy combines risk cover with the savings and investment. If the policy holder dies during the policy time, he will get the assured amount. Even if he survives he will receive the assured amount. The advantage of this policy is if the policy holder survives after the completion of policy tenure, he receives assured amount plus additional benefits like Bonus, etc. In this kind of policy, policy holder receives huge amount while completing the tenure. In addition to the basic policy, insurers offer various benefits such as double endowment and marriage/ education endowment plans. The cost of such a policy is slightly higher but worth its value.

\section{iv. Money Back Policy}

Money Back Policy is to provide money on the occasions when the policy holder needs for his personal life. The occasions may be marriage, education, etc. Money will be paid back to the policy holder with the specified duration. If the policy holder dies before the policy term, the sum assured will be given to his family. A portion of the sum assured is payable at regular intervals. On survival the remainder of the sum assured is payable.

\section{v. Annuities and Pension}

An annuity is a series of periodic payments. An annuity contract is an insurance policy, under which the annuity provider (insurer) agrees to pay the purchaser of annuity (annuitant) a series of regular periodical payments for a fixed period or during someone's life time. In an annuity, the 
insurer agrees to pay the insured a stipulated sum of money periodically. The purpose of an annuity is to protect against risk as well as provide money in the form of pension at regular intervals. Over the years, insurers have added various features to basic insurance policies in order to address specific needs of a cross section of people

\section{LIC Jeevan Akshay VI}

LIC Jeevan Akshay VI policy is basically a single premium immediate annuity scheme that persons can buy easily by paying a lump sum amount. It is a non-unit-linked pension plan. It offers annuity payment of a fixed amount extending for a life time.

\section{LIC e-Term Plan}

LIC's e-Term is a form of pure life cover policy which offers financial protection to the policyholder's family in case of any regrettable event. It is also named as regular premium nonparticipating (without bonus) plan. This insurance policy will be available through on-line application process only hence there are no mediators.

\section{LIC New Children's Money Back Plan}

This plan was launched on 4th March, 2015. It is basically a non-linked, with-profit regular premium payment policy which mainly aims to meet education, marriage and other financial requirements of growing children. In addition, this insurance policy also offers risk coverage to the insured child during the policy term. That's why; it can be measured as a saving cum protection plan. Maturity life of the policy is 25 years.

\section{LIC Jeevan Sangam}

LIC Jeevan Sangam was introduced on 4th March, 2015 with Children's money back plan. It is a single premium, non-linked and guaranteed-return plan. The premium depends upon two thingsage of the insured and maturity sum assured. It can be taken by anyone whose age from 6 to 50 years. It is a single premium payment and tenure of the policy is 12 year.

These are the policies which are mostly preferred by customers. In addition to this, various new generation policies are also offered by LIC

\section{FINDINGS OF THE STUDY}

Based on the data collected and analyzed, the following findings are made.

1) Majority of the policy holders are satisfied with their current insurance plans

2) Majority of the customers (68\%) are unaware of various schemes of insurance policies

3) Most of the policy holders (63\%) are not satisfied with the service of insurance agents

4) Majority of the respondents opinioned that claim settlement procedures are not satisfactory.

5) Most of the respondents prefer the policy Jeevan Anand so that they are much benefited

6) Most of the respondents are taken insurance policies with a view to gain tax advantage

7) Pension plans are the second type of policy preferred by policy holders

\section{SUGGESTIONS FOR IMPROVEMENT}


Based on the findings of the study, the following suggestions are put forward

1) The life insurance corporation must conduct financial training and awareness programmes to customers to improve their level of awareness

2) LIC must take necessary steps to improve the performance of agents and staffs

3) Make relaxation in the claim settlement procedures

4) More research is to be conducted to identify the problems faced by customers and take remedial measures to overcome these problems.

5) Wide publicity should be given about the types of policies and benefits particularly in rural areas.

\section{REFERENCES}

[1] Basics of banking and insurance, jagroop singh, Kalyani publications

[2] Banking and insurance -Theory and practice ,K.Venugoplan , Abdul assis koroth , Calicut university publications

[3] Prabandhan : Indian journal of management, vol 7(3), feb 2015

[4] EPRA international journal of economic and business review

[5] International journal of social science research

[6] International journal of research-Granthaalayah 